\title{
Rancang Bangun Aplikasi Berbasis Android Untuk Pembelajaran Linux Centos
}

\author{
Rusady $^{1}$, Sari Dewi ${ }^{2}$, Rian Septian Anwar ${ }^{3}$ \\ ${ }^{1}$ Program Studi Teknologi Komputer, Fakultas Teknik dan InformatikaUniversitas Bina Sarana Informatika Jl. \\ Kramat Raya No.98, Jakarta Pusat, DKI Jakarta 10450,Indonesia \\ ${ }^{2}$ Program Studi Sistem Informasi PSDKU Pontianak, Fakultas Teknik dan Informatika Universitas Bina Sarana \\ Informatika, Jl. Abdulrahman Saleh No.18, Pontianak, Kalimantan Barat ,Indonesia \\ ${ }^{3}$ Program Studi Ilmu Komputer, Fakultas Teknik dan InformatikaUniversitas Bina Sarana Informatika Jl. Kramat \\ Raya No.98, Jakarta Pusat, DKI Jakarta 10450,Indonesia \\ e-mail: $\underline{1}$ rusadidoank@gmail.com, ${ }^{2}$ sari.sre@bsi.ac.id, $\underline{3}$ rian.ptn@bsi.ac.id
}

Artikel Info : Diterima : 15-06-2021 | Direvisi : 25-06-2021 | Disetujui : 30-06-2021

\begin{abstract}
Abstrak - Centos adalah kerangka kerja berbasis Linux yang umumnya digunakan oleh pengawas jaringan. Mengingat rencana pendidikan pembelajaran di program studi inovasi PC saat ini, mahasiswa mengenal kerangka kerja ini. Di zaman serba mekanik sekarang ini banyak sekali media pembelajaran seperti aplikasi android. Aplikasi ini dibuat untuk menawarkan kenyamanan yang berbeda dengan bahasa pemrograman Java. Selain itu, aplikasi ini juga dikembangkan menggunakan model SDLC. Masih ada beberapa kegunaan yang dapat membantu latihan pembelajaran, terutama yang berkaitan dengan kerangka kerja linux Centos, penjelasan mendasar pembuat aplikasi membuat aplikasi yang nantinya dapat membantu mempelajari tentang Centos linux. Meskipun tidak sepopuler framework kerja Windows dan iOS, namun masih banyak yang menggunakan framework Centos Linux, terutama untuk kebutuhan framework kerja dengan aplikasi ini memudahkan penguna untuk mempelajari karna berbasis mobile sehingga kita bisa belajar Centos dimana saja dan kapan saja.
\end{abstract}

Kata Kunci: Centos, Android, pembelajaran

Abstracts - Centos is a Linux based framework commonly used by network supervisors. Given the educational plan of learning in the current PC innovation study program, students are familiar with this framework. In today's all-mechanical era, there are lots of learning media such as android applications. This application was created to offer a different convenience to the Java programming language. In addition, this application is also developed using the SDLC model. There are still some uses that can help with learning exercises, especially those related to the Centos linux framework, the basic explanation of application makers to create applications that can later help learn about Centos linux. Although not as popular as Windows and iOS frameworks, there are still many who use the Centos Linux framework, especially for framework needs with this application making it easier for users to learn because it is mobile based so that we can learn Centos anywhere and anytime.

Keywords: Centos, Android, learning

\section{PENDAHULUAN}

Android adalah sistem operasi yang populer di kalangan pengguna smartphone non-iOS dan Windows Phone karena memungkinkan pengguna untuk membuat aplikasi seluler secara gratis. Oleh karena itu, banyak developer mulai membuat dan mengembangkan berbagai jenis aplikasi berbasis Android. (Application, Childhood, \& Based, n.d.) Android menyediakan memori khusus untuk aplikasi Android yaitu playstore, beberaa aplikasi sudah tersedia di playstore, sesuau kebutuhan. anda hanya perlu mendownload dan menginstall di smartphone anda, kita dapat dengan mudah melakukan aktivitas sehari-hari, baik itu fashion, office, games ataupun bahkan berbagai aplikasi yang dapat mendukung dalam bidang pendidikan, meskipun tidak semua aplikasi yang

97

This work is licensed under a Creative Commons Attribution-ShareAlike 4.0 International License. 
dibuat oleh programmer menyediakan semua materi yang kita butuhkan (Wiranda \& Adri, 2019), karena sifatnya yang open source dan tersedianya berbagai jenis perangkat lunak pendukung, antara lain Eclipse dan Netbeans yang mudah dipahami oleh pemula, dan banyak panduan, baik online maupun offline, yang menjelaskan secara lengkap prosedur pengembangan aplikasi Android, yang memungkinkan kita untuk membuat aplikasi Anda sendiri.

Belajar mengajar di kelas tidak selalu efektif dan menyenangkan, apalagi jika berhadapan dengan banyak modul materi pelajaran, buku yang tebal membuat kita enggan untuk mempelajari dan mendalaminya, untuk itu diperlukan inovasi-inovasi yang dapat menjadikan pembelajaran dalam kehidupan sehari-hari, akan lebih menyenangkan (Putri et al., 2019), Terdapat juga beberapa aplikasi yang dapat membantu proses belajar mengajar khususnya yang berkaitan dengan sistem operasi Linux Centos, Hal ini pula yang menjadi alasan utama penulis membuat aplikasi yang dapat membantu Anda mempelajari Linux Centos. Meski tidak sepopuler sistem operasi Windows dan iOS, masih banyak orang yang menggunakan sistem operasi Linux. Centos terutama membahas kebutuhan sistem operasi server dan administrator jaringan serta bahan ajar khususnya bahan kuliah.

CentOS (Community Enterprise Operating System) merupakan proyek komunitas yang dimulai pada akhir tahun 2003 untuk menyediakan sistem operasi pada skala perusahaan. Untuk itu, CentOS telah dibangun kembali menggunakan kode akses yang dirilis dengan Red Hat Enterprise Linux (RHEL) untuk memperkenalkan Linux dengan kualitas dan kompatibilitas yang hampir sama sambil memberikan patch keamanan berkala untuk semua paket perangkat lunak terkait (Teknologi et al., 2020). CentOS adalah distribusi Linux yang paling banyak digunakan untuk server di luar Debian GNU / Linux CentOS secara aktif dikembangkan oleh sekelompok tim inti dan didukung oleh komunitas pengguna korporat, administrator jaringan, administrator sistem, dan Pengembang Linux lainnya.

\section{METODE PENELITIAN}

Metode penelitian yang digunakan penulis adalah metode Studi Kepustakaan, yaitu mengunduh atau mengumpulkan data dari buku, majalah, artikel di internet dan e-book tentang perancangan aplikasi Android. Selain itu penulis juga menggunakan metode System Development Life Cycle (SDLC), yang terdiri dari beberapa tahapan (Dharmawan, Purwaningtias, \& Risdiansyah, 2018) yaitu:

1. Analisis

Tahap ini adalah proses menganalisis kebutuhan, kebutuhan dan aplikasi ini, apa saja yang dibutuhkan dalam aplikasi yang akan dibangun. Pada langkah ini akan dihasilkan data-data terkait keinginan pengguna saat membuat aplikasi, termasuk rencana yang akan dijalankan.

2. Desain

Proses desain ini akan menerjemahkan kebutuhan ke dalam desain aplikasi yang dapat dievaluasi sebelum eksekusi kode. Proses ini akan fokus pada perancangan struktur data, arsitektur aplikasi representasi antarmuka (Wisnu Uriawan, 2017)

3. Implementasi

Tahapan ini merupakan proses implementasi hasil desain yang telah dihasilkan dengan mengembangkan aplikasi menggunakan bahasa pemrograman Java Android dengan Netbeans sebagai editornya (Syakur \& Anamisa, 2018).

4. Pengujian

Dapat dikatakan bahwa tahap ini merupakan tahap akhir dari aplikasi. Pada tahap ini, aplikasi yang telah diajukan untuk diperbaiki jika terjadi kesalahan diuji dan dievaluasin.

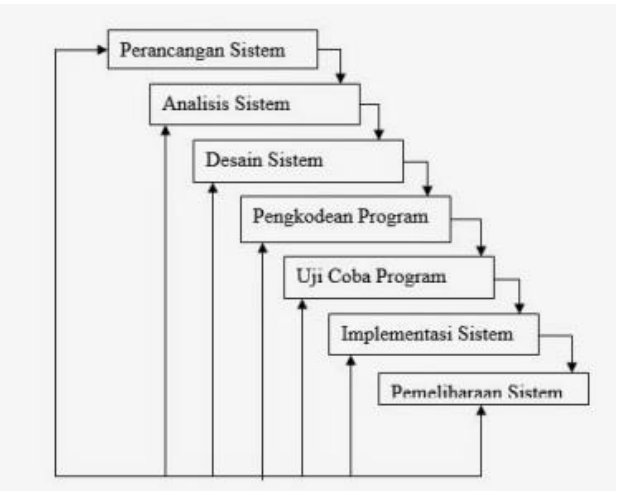

Sumber: (Maiyana, Informatika, By, \& Simpang, 2018) 
A. Perangkat Lunak (Software), terdiri atas:

1) Sistem Operasi Windows Seven Ultimate x64 bit.

2) Java Development Kit (JDK).

3) Software Development Kit (SDK).

4) Android Development Kit (ADT).

5) IDE Android yang berupa Eclipse dan Android plugin untuk Eclipse.

B. Bahan Penelitian

Dalam kegiatan penelitian ini penulis menggunakan bahan penelitian antara lain :

1. Modul Pembelajaran Linux Administrator

2. Buku-buku yang berkaitan dengan Linux Centos.

3. Buku-buku yang berkaitan dengan pemrograman Android.

C. Teknik Pengujian

Teknik pengujian yang digunakan dalam menyusun penelitian ini adalah teknik pengujian Black Box.

\section{HASIL DAN PEMBAHASAN}

Untuk membuat sebuah program tentunya harus memahami kebutuhan apa saja yang diharapkan untuk membuat sebuah program dengan tujuan agar hasil dan interaksi pembuatan program tersebut sesuai dengan yang diinginkan. Pembuat merinci persyaratan apa yang diharapkan untuk membuat aplikasi berbasis android tentang Linux Centos. Akibat dari investigasi yang dilakukan pencipta antara lain :

1. Analisis Users

Penguna Aplikasi yang dibuat penulis merupakan aplikasi strategi pembelajaran yang sebagian besar klien adalah mahasiswa untuk itu aplikasi yang dibuat harus menjunjung tinggi materi yang dibutuhkan oleh mahasiswa termasuk total materi sebagai pengganti buku, teknik Memperkenalkan Linux Centos di PC dan program yang akan dihasilkan mudah dipahami.

2. Pengujian

Aplikasi Gadget Ponsel buatan klien disesuaikan dengan peningkatan inovasi berbasis Serbaguna, khususnya kerangka kerja yang digunakan dengan memanfaatkan varian 2.3 (Gingerbread) kemudian, maka aplikasi selanjutnya dapat digunakan pada framework kerja android Gingerbread hingga Kitkat terbaru.

3. Kebutuhan Peralatan

PC Produk dan peralatan yang dibutuhkan oleh pencipta untuk membuat aplikasi pembelajaran Linux Centos berbasis Android dilengkapi dengan gadget yang mumpuni, terutama peralatan yang diharapkan dapat membantu menjalankan pemrograman yang diperlukan. Penulis menggunakan prosesor komputer Intel ${ }^{\circledR}$ Pentium® N3540 @ 2.16 GHz 2.16 GHz dengan Smash 2 GB untuk memiliki opsi untuk menjalankan aplikasi Netbeans 7.2 dan Emulator sedangkan tujuan dasar untuk Android yang penulis buat adalah bentuk Android 2.3 (Gingerbread) .

\subsection{Spesifikasi Rancangan Program}

Dalam spesifikasi program ini, penulis menjelaskan tentang spesifikasi bentuk uraian pembuatan progam yang akan penulis gunakan, diantaranya adalah:

\subsubsection{Flowchart}

Sebelum penulis membuat rancangan tampilan penulis membuat alur program yang akan dibentuk terlebih dahulu yang biasa di sebut flowchart. Adapun flowchart dari aplikasi yang akan dibuat penulis adalah: 


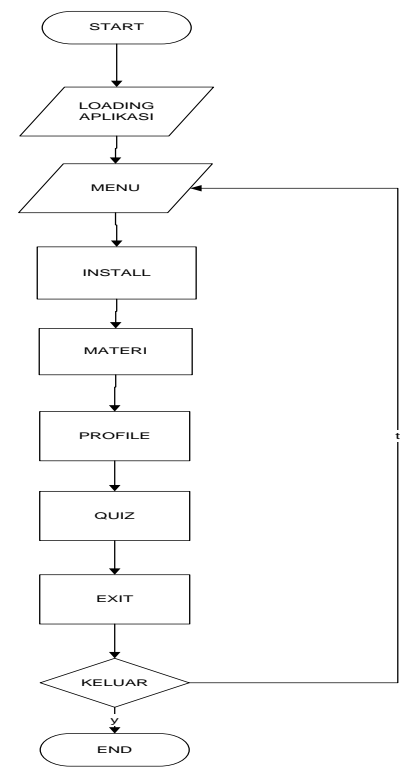

Sumber: Penelitian 2021

Gambar 2 Flowcart Menu Utama.

\subsubsection{Perancangan Tampilan Aplikasi}

Pada tahapan ini akan dijelaskan mengenai bentuk tampilan pada tiap halaman yang terdapat di dalam aplikasi ini. Tampilan halaman-halaman tersebut akan lebih dijelaskan sebagai berikut:

1. Perancangan Tampilan Halaman Loading

Saat pengguna meluncurkan aplikasi ini untuk pertama kalinya, layar halaman pemuatan dimulai. Tampilan ini memiliki ImageView dan ProgressBar. Layarnya ditunjukkan pada gambar di bawah ini.

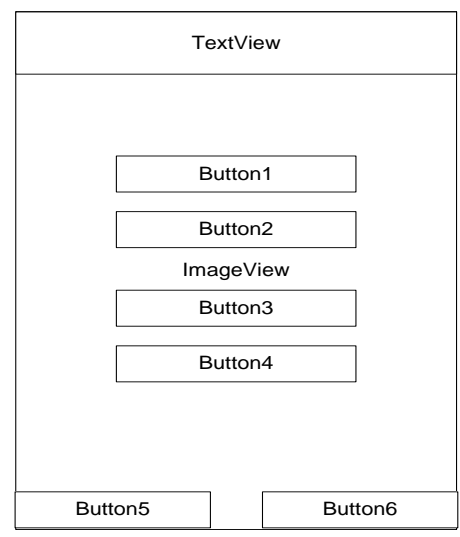

Sumber: Penelitian 2021

Gambar 3. Layout Menu Utama

\subsubsection{Spesifikasi Bentuk Keluaran (Implementasi)}

Pembuatan antarmuka showcase pada framework android dilakukan sebagai XML. Setiap komponen di antarmuka harus ditambahkan dengan karakteristik pengenal, sehingga komponen akan dibuat di kelas aset dan membuatnya lebih mudah digunakan di kelas yang membutuhkannya. Desain menu merupakan format dasar yang tetap berjalan selama aplikasi berjalan sedangkan tombol menu yang dijalankan akan berjalan di atas prinsip running design (Maiyana et al., 2018).

\section{A. Implementasi Tampilan Loading}

Pembuatan antar muka yang pertamakali akan dijalankan pada saat aplikasi berjalan adalah tampilan yang dibangun pada activity_main.xml dan di jalankan oleh CentOS.java terdapat penggunaan beberapa widget button yang dibangun didalam widget layout LinearLayout.

Pada tampilan yang dibangun didalam file activity_main hanya terdapat picture dan progressbar yang dijadikan tampilan. 


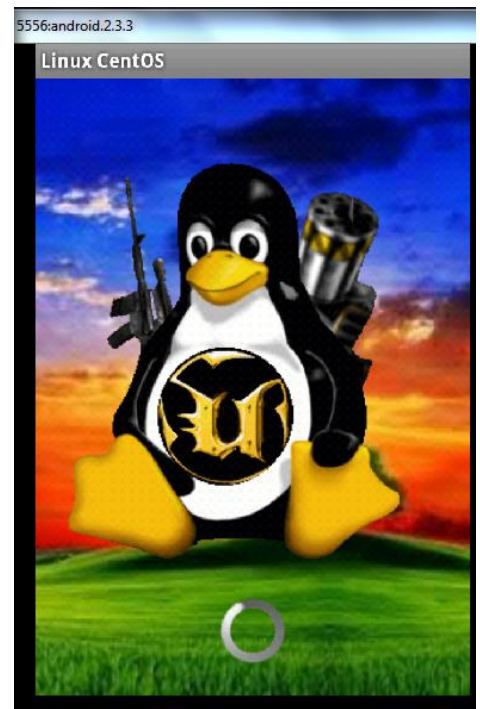

Sumber: Penelitian 2021

\section{B. Implementasi Menu Utama}

Gambar 4. Tampilan Awal

Pada tampilan ini terdapat penggunaan beberapa widget yang dibangun didalam widget AbsoluteLayout. Pada AbsoluteLayout, tampilan widget-widget yang terdapat didalamnnya dapat disusun dengan ketentuan yang sudah ditetapkan menyesuaikan orientasi pada perangkatnya(Putera et al., 2017)

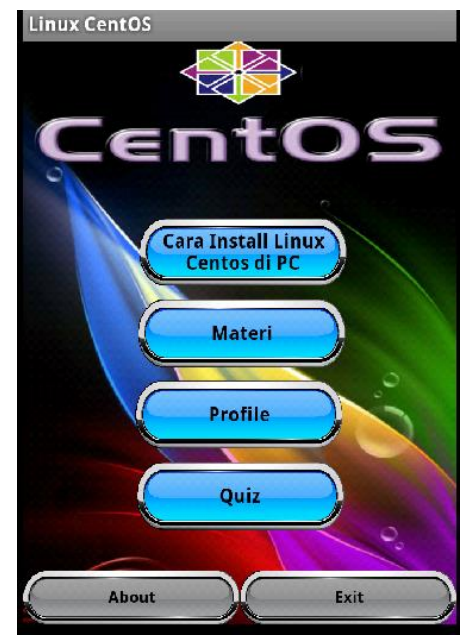

Sumber: Penelitian 2021

\section{Implementasi Halaman Materi}

Gambar 5. Menu Utama

Pada halaman materi akan menjelaskan beberapa materi tentang Linux CentOS yang di bagi ke dalam beberapa bagian pada halaman materi ini menggunakan ListView yang di dalamnya terdapat menu dari materi yang akan di bahas. Berikut tampilan hasilnya. 


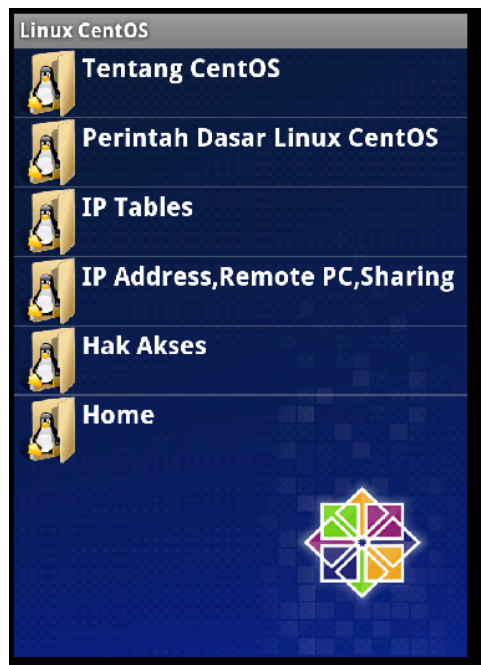

Sumber: Penelitian 2021

\section{Implementasi Halaman Quiz}

Gambar 6.Tampilan menu About

Pada halaman ini menggunakan timer yang di import dari java. Logikanya ketika button quiz di klik maka akan muncul menu quiz dan disitulah awal mula dari timer di mulai. Timer untuk quiz ini dibatasi selama 2 menit. Jika waktu sudah habis tetapi soal belum terselesaikan semua maka akan langsung muncul tulisan times up dan muncul form hasil. Quiz ini terdiri dari 20 soal yang di simpan di SQLite Database, namun disini tantangannya ketika ada jawaban salah makan quiz akan berhenti di soal tersebut dan muncul tampilan namun ketika jawaban benar maka anda akan di arahkan ke soal selanjutnya.

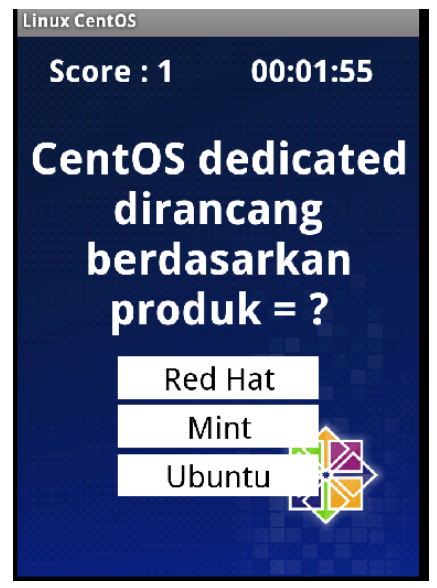

Sumber: Penelitian 2021

Gambar 7 .Tampilan menu About

\subsubsection{Spesifikasi File}

Langkah-langkah pembuatan aplikasi ini dengan menentukan class-class apa saja yang dibutuhkan untuk membangun sebuah aplikasi. Pada aplikasi ini terdapat penggunaan file.xml. Pada android, java digunakan untuk memanggil layout yang telah dibuat menggunakan XML (Much. Sobri Sungkar, 2017). Layout pada aplikasi ini dibuat menggunakan xml, untuk menyimpan media gambar disimpan di folder drawable yang ada di folder resource, adapun pada value string. $x m l$ berfungsi untuk menampilkan nama pada icon aplikasi. Kemudian untuk mengkonfigurasi aplikasi di android harus di setting di file manifest yang terdapat di folder important files, di file ini kita dapat mengkonfigurasi nama paket, minimum sdk, kode versi, nama versi, dan akses ke OS. Manifest ini sebagai fungsi utama pusat pengendali informasi aplikasi dan activity. 


\subsubsection{Spesifikasi Program}

Sistem yang berjalan pada aplikasi ini adalah:

a. Sebuah. Saat aplikasi dijalankan, pengguna dihadapkan dengan formulir pemuatan. Setelah muncul form kebanyakan halaman, yang terdiri dari menu install, materi, kuis, dan profil.

b. Jika pengguna ingin masuk ke form install, pengguna harus menekan tombol install pada tampilan menu terlebih dahulu. cara ini berisi prosedur untuk menginstal Linux CentOS 7 sebagai server.

c. Ketika pengguna menekan tombol fabric pada tampilan menu, maka akan masuk ke form penempatan fabric dari CentOS linux.

d. Ketika pengguna menekan tombol kuis pada tampilan menu, pengguna diarahkan ke tampilan yang berisi kuis tentang materi linux CentOS.

e. Tombol profil digunakan untuk menampilkan informasi tentang pembuat aplikasi ini.

f. Tombol Tentang digunakan untuk menampilkan informasi tentang aplikasi ini.

g. tombol keluar digunakan untuk keluar dari aplikasi.

1.Hasil Uji Coba Tampilan Hasil Quiz

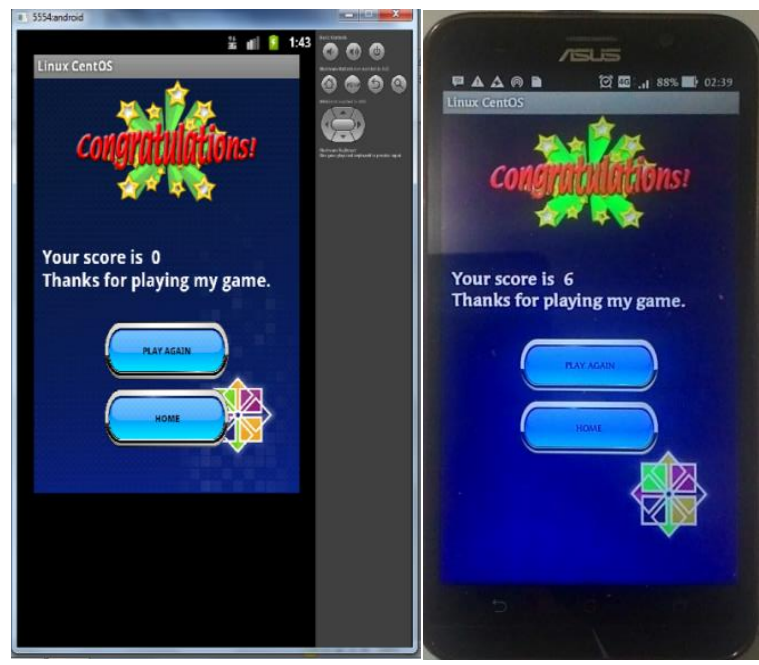

Sumber: Penelitian 2021

Gambar 8: Hasil Uji Coba Tampilan Hasil Quiz

2.Hasil Uji Coba Menu Cara Instalasi CentOS

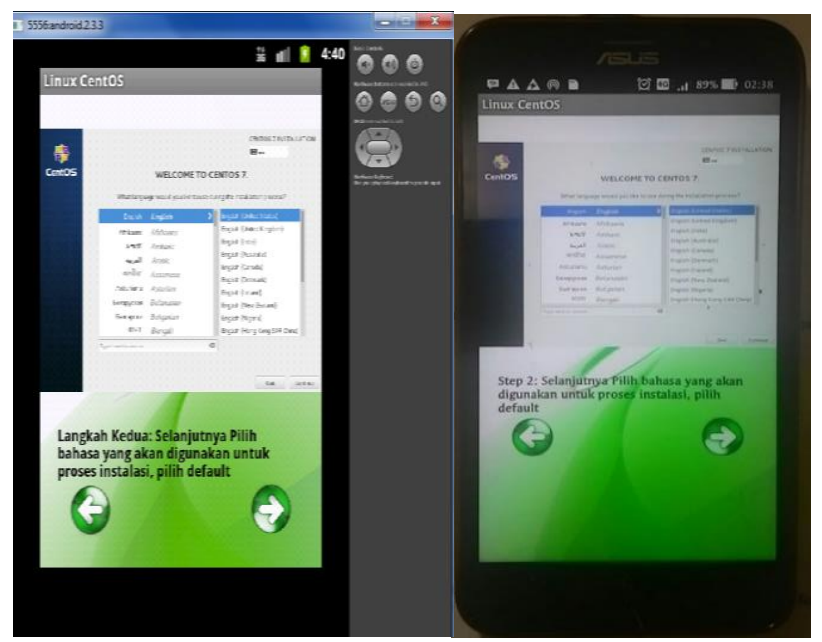

Sumber: Penelitian 2021

Gambar 9: Hasil Uji Coba Menu Cara Instalasi CentOS 


\subsubsection{Hasil Pengujian}

Berdasarkan pengujian aplikasi yang telah dilakukan maka dihasilkan rekapitulasi hasil pengujian sebagai berikut:

Tabel 1. Hasil Pengujian Aplikasi

\begin{tabular}{|c|c|c|c|c|c|c|c|c|}
\hline No & $\begin{array}{l}\text { Pengujian } \\
\text { Aplikasi }\end{array}$ & $\begin{array}{l}\text { Expected } \\
\text { Result }\end{array}$ & $\begin{array}{l}\text { Jumlah } \\
\text { Sesuai }\end{array}$ & \multicolumn{2}{|c|}{ Presentase Sesuai } & $\begin{array}{l}\text { Jumlah } \\
\text { Tidak } \\
\text { Sesuai }\end{array}$ & \multicolumn{2}{|l|}{$\begin{array}{l}\text { Presentase } \\
\text { Tidak Sesuai }\end{array}$} \\
\hline 1. & Menu & 6 & 6 & $\begin{array}{l}(6 / 6) * \\
=100 \%\end{array}$ & $100 \%$ & 0 & $\begin{array}{l}(0 / 6)^{*} 100 \% \\
=0 \%\end{array}$ & \\
\hline 2. & Gambar & 28 & 28 & $\begin{array}{l}(28 / 28) * 10 \\
=100 \%\end{array}$ & & 0 & $\begin{array}{l}(0 / 28) * 100 \% \\
0 \%\end{array}$ & 6 \\
\hline 3. & Suara & 28 & 28 & $\begin{array}{l}(28 / 28) * 10 \\
=100 \%\end{array}$ & & 0 & $\begin{array}{l}(0 / 28) * 100 \% \\
0 \%\end{array}$ & $b$ \\
\hline 4. & Bahasa & 4 & 4 & $\begin{array}{l}(4 / 4) * \\
=100 \%\end{array}$ & $100 \%$ & 0 & $\begin{array}{l}(0 / 4)^{*} 100 \% \\
=0 \%\end{array}$ & \\
\hline 5. & Instalasi & 3 & 3 & $\begin{array}{l}(3 / 3) * \\
=100 \%\end{array}$ & $100 \%$ & 0 & $\begin{array}{l}(0 / 3) \\
=0 \%\end{array}$ & $100 \%$ \\
\hline 6. & Quiz & 21 & 21 & $\begin{array}{l}(21 / 21) \\
=100 \%\end{array}$ & $100 \%$ & 0 & $\begin{array}{l}(0 / 21) * \\
=0 \%\end{array}$ & $100 \%$ \\
\hline TOTAL & 103 & 103 & $\begin{array}{l}(95 / 103) * 100 \% \\
=100 \%\end{array}$ & 0 & & $(0 / 103) * 100 \%=0 \%$ & & \\
\hline
\end{tabular}

Sumber :Penelitian 2021.

Dari hasil rekapitulasi pengujian yang dilakukan maka diketahui dari 95 expected result terdapat 103 pengujian yang sesuai dengan indikator atau sebesar 100\% dan pengujian tidak sesuai dengan indikator yang diharapkan sebanyak 0 atau sebesar $0 \%$. Dari hasil pengujian dan data yang didapatkan tersebut dapat disimpulkan bahwa pengujian aplikasi pembelajaran centos, di anggap valid.

\section{KESIMPULAN}

Setelah dilakukan pengujian dan analisa pada aplikasi Linux CentOS maka diperoleh beberapa kesimpulan sebagai berikut, Aplikasi Linux CentOS berbasis android dapat dijadikan alternatif sebagai media pembelajaran linux centos pengganti dari modul dan buku panduan, dengan aplikasi ini pengguna dapat mengetahuai tata cara installasi Linux CentOS dan materi dari Linux CentOS itu sendiri,dengan adanya Quiz pada aplikasi ini pengguna dapat menguji pemahaman tentang Linux CentOS.

\section{REFERENSI}

Application, D., Childhood, E., \& Based, E. (n.d.). Rancang Bangun Aplikasi Pembelajaran Anak Usia Dini Berbasis Mobile. 1-10.

Dharmawan, W. S., Purwaningtias, D., \& Risdiansyah, D. (2018). Penerapan Metode SDLC Waterfall Dalam Perancangan Sistem Informasi Administrasi Keuangan Berbasis Desktop. VI(2).

Maiyana, E., Informatika, M., By, J., \& Simpang, P. (2018). PEMANFAATAN ANDROID. JURNAL SAINS DAN INFORMATIKA, 1, 54-67.

Much. Sobri Sungkar, M. K. (2017). Susunan Redaksi. Power Elektronik Vol. 6 No. 1 Januari 2017, 6(1), $12-16$.

Putera, J. M., Irwansyah, M. A., Sukamto, A. S., Prof, J., Nawawi, H. H., \& Pontianak, K. (2017). Rancang Bangun Aplikasi Berbasis Android dengan Penerapan Web Service pada Sistem Informasi Perpustakaan ( Studi Kasus : Perpustakaan Daerah Kalimantan Barat ). Justian, 5(1).

Putri, D. B., Anjarwani, S. E., Afwani, R., Studi, P., Informatika, T., Teknik, F., \& Mataram, U. (2019). RANCANG BANGUN APLIKASI PENDUKUNG PEMBELAJARAN ILMU PENGETAHUAN SOSIAL ( IPS ) SEKOLAH DASAR BERBASIS ANDROID ( Design and Development of Supporting Applications for Android-based Primary. 1(1), 49-56.

Syakur, M. A., \& Anamisa, D. R. (2018). Rancang Bangun Aplikasi Pembelajaran Rambu-Rambu Lalu Lintas Berbasis Android Untuk Siswa Sekolah Dasar. 4(1).

Teknologi, J., Mura, I., Irawan, D., Irawan, D., Studi, P., Informatika, T., .. Darma, U. B. (2020). PERBANDINGAN INTRUSION PREVENTION SYSTEM ( IPS ) PADA LINUX. 12(02), 131-144.

Wiranda, T., \& Adri, M. (2019). RANCANG BANGUN APLIKASI MODUL PEMBELAJARAN TEKNOLOGI WAN BERBASIS ANDROID Tio Wiranda $1 *$, Muhammad Adri 2 1. 7(4).

Wisnu Uriawan, H. H. (2017). Edisi Juni 2017 Volume X No. 2. Jurnal ISTEK, X(2), 107-122. 